\title{
Wave of protest strikes Europe's universities
}

Laura Nelson

Discontent is sweeping through European universities this winter, as academics protest against stagnant salaries, dwindling career prospects and increasing demands made on them by their employers.

In France, Italy and the United Kingdom, the protests have drawn tens of thousands of scientists into a spree of militancy not seen for decades. Many doubt that their protests will have much impact on their politician paymasters. But, disillusioned by years of what they see as disrespect for their chosen vocation, most are joining in the protests if only to make the point that they are unhappy with the status quo.

In Britain, a proposed fee structure that will end the tradition of free tuition for undergraduates has combined with an unwelcome new pay structure for academics to trigger campus unrest. The Association of University Teachers (AUT), the main academic teachers' union, called its 48,000 members out on one-day strikes during 23-27 February, and says that $90 \%$ of them took action.

On a picket line outside University College London on 25 February, student supporters of the action were in boisterous mood, but the handful of dutiful scientists present found little to smile about. "We're all a bit disillusioned," grumbled John Pollard, an electrical engineer, who said that he has never been on strike before. Other strikers said that they were frustrated at what they

\section{French scientists prepare for mass resignation}

French scientists were meeting in Paris this week to decide whether to go through with their threat to resign all management duties. The ultimatum hinged on the government taking immediate and significant steps to boost French research. But as Nature went to press, the movement's leaders remained adamant that many researchers would quit.

The mass resignation would be the culmination of a bitter winter of protests by researchers in government laboratories and universities. They say that President Jacques Chirac and Prime Minister Jean-Pierre Raffarin have failed to keep funding promises, or to consult with them about a strategy paper that is being prepared on the future of French research.

The resignation pledge was instigated by a grass-roots body called Save Research (see Nature 427, 276; 2004), which has so far attracted some 66,000 signatures. If implemented, it could quickly paralyse the laboratory system: lab heads, for example, are legally responsible for security, so their departure could mean that labs will be unable to open their doors. It may also become impossible for staff to view as the government's general neglect of higher education.

The AUT says that its members are putting up with the low pay that accompanies academic work, while their increasingly regimented working environment has come to resemble that of better-paid peers in the private sector. "We want respect for people who have been delivering against every benchmark they have been set for the past decade," says Sally Hunt, the union's general secretary.

Other scientists mutter that the protests won't help. "Of course academics aren't paid enough," says one anonymous neuroscientist at the University of Oxford. "But striking won't do any good. Unlike a bus driver,

order supplies or get permission to travel.

In the run up to this week's meeting, the government announced concessions to head off the revolt, including an offer of a multi-year funding plan for research, but these have so far been rejected by the protesters (see page 105). On 5 March, Raffarin and science minister Claudie Haigneré discussed the crisis with Étienne-Émile Baulieu and Édouard Brézin, the president and vice-president, respectively, of the French Academy of Sciences.

Baulieu and Brézin have offered to mediate between the government and the protesters. They proposed the creation of an independent high-level committee, including members of Save Research, to ensure scientific participation in the strategy paper, plans for which were announced at the start of the year by Chirac. Raffarin accepted the idea, says Brézin.

The promise of a funding plan for science would usually hearten researchers, Brézin notes, but not in the current climate. "There is a crisis of confidence in the government," he says. Declan Butler

http://recherche-en-danger.apinc.org

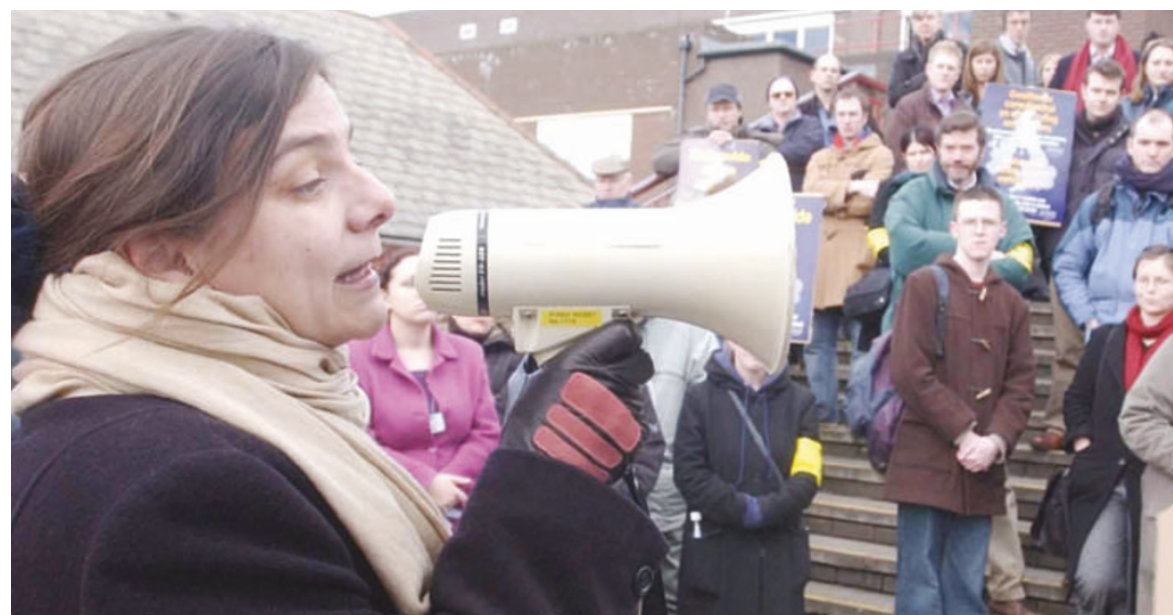

All out: union leader Sally Hunt addresses pickets at Cardiff University during a week of action.

nobody cares when a scientist goes on strike."

The AUT has sought to increase its leverage by asking its members to boycott student assessments, including the acceptance of PhD theses, from 1 March. But scientists are not keen to take this step. "It is unlikely that we will boycott assessments," says Pollard. "We are too committed to our students."

French academics are taking a more aggressive approach to their grievances. Half of the country's scientific administrators were threatening to resign from their management duties this week in protest at low research funding levels and job cuts (see left). "This is the first time the protests have been on such a large scale," says Alain Trautmann, a cell biologist at the Cochin Institute in Paris.

In Italy, most young academic scientists took part in two one-day strikes in February and March to protest at a draft law, released on 16 January, that restructures professorships, sharply increases minimum teaching hours and assigns control of university posts to the government. Giovanna Grimaldi, a geneticist at the Institute of Genetics and Biophysics in Naples, says that the proposed change "breaks the autonomy of universities", adding that the most worrying aspect of the plan is that it would "control people" and take away their independence.

All this has led to an explosion of frustration, says Grimaldi, which she thinks is damaging the attractiveness of a scientific career. "Now young scientists go away to the United States, and they don't come back," she says.

This brain drain of talent from European science - driven in large part by greater salaries and career opportunities in the United States - is a theme commonly aired by protesters in each country. Peter Cotgreave, director of the pressure group Save British Science, says that a widespread sense that "the grass is greener in the United States" is helping to keep European researchers feeling blue. 